\title{
Wildfires as a major driver of landscape dynamics in three fire-prone areas of Portugal
}

\author{
Joaquim S. Silva*, Pedro Vaz, Francisco Moreira, Filipe Catry, Francisco C. Rego \\ Centre of Applied Ecology “Prof. Baeta Neves”, Institute of Agronomy, Technical University of Lisbon, 1349-017 Lisbon, Portugal
}

\section{A R T I C L E I N F O}

\section{Article history:}

Received 24 October 2010

Received in revised form 28 February 2011

Accepted 3 March 2011

Available online 11 April 2011

\section{Keywords:}

Wildfires

Landscape changes

Land abandonment

Transition matrices

Exotic species

Portugal

\begin{abstract}
A B S T R A C T
Wildfires are a common event in Mediterranean landscapes. We assessed the implications of wildfires on the landscape dynamics of three fire-prone areas of Central and Northern Portugal during a time period of 13-15 years, starting in 1990. Using an information-theoretical approach and probability analysis, we assessed the relative importance of fire and initial land cover on the overall landscape dynamics. We further explored the role of fire on specific land cover dynamics by building transition matrices separately for burned and unburned areas. Finally we simulated future landscapes using the transition matrices to project landscape composition, according to a Markovian process. Fire had a determinant role in the landscape changes observed in the three study areas, as it favored shrubland persistence and the conversion of other land cover types to shrublands and mixed forests. The effect of fire on land cover dynamics could be explained mainly by post-fire vegetation responses due to land abandonment, but human-driven changes were also an important influence on land cover dynamics. In the long term, the current landscape dynamics would result in an increase in landscape diversity. When compared with this projection, either a scenario without fire or a complete periodic burn of the study areas, would result in lower landscape diversity. Comparing the two opposite scenarios, the latter would reduce the proportion of agriculture, while increasing the proportion of shrublands and unmanaged mixed forests of exotic and native species, therefore leading to an increase of fire hazard and to less sustainable landscapes.
\end{abstract}

(c) 2011 Elsevier B.V. All rights reserved.

\section{Introduction}

Wildfires constitute a major disturbance in Mediterranean landscapes (Rundel, 1998) and have profound consequences in landscape structure and functioning (Bajocco \& Ricotta, 2008). The relationship between fire and landscape pattern and dynamics is one of strong reciprocal influence. On one hand, landscape pattern will influence fire spread, as certain land cover types are more fire-prone than others due to differences in vegetation structure, moisture content, and fuel load composition (e.g. Forman, 1995; Mermoz, Kitzberger, \& Veblen, 2005; Moreira, Vaz, Catry, \& Silva, 2009). On the other hand, fire occurrence will subsequently affect landscape pattern and dynamics (Lloret, Calvo, Pons, \& Díaz-Delgado, 2002; Viedma, 2008) by changing vegetation structure and soil processes according to the fire adaptations of each ecosystem (Mouillot, Ratte, Joffre, Mouillot, \& Rambal, 2005; Pausas, Llovet, Rodrigo, \& Vallejo, 2008; Viedma, 2008). In the case

\footnotetext{
* Corresponding author. Tel.: +351 239802284; fax: +351239802979

E-mail addresses: jss@esac.pt (J.S. Silva),zazvaz@gmail.com (P. Vaz), fmoreira@isa.utl.pt (F. Moreira), fcatry@isa.utl.pt (F. Catry), frego@isa.utl.pt (F.C. Rego).
}

of Mediterranean-type ecosystems, many authors refer a strong resilience allowing the persistence of plant communities after fire (e.g. Mitchell, Simonson, Flegg, Santos, \& Hall, 2009; Naveh, 1975; Trabaud \& Galtiè, 1996). But on Mediterranean landscapes, where human management is widespread, human activities may also interact with fire in different ways. Some studies have shown that post-fire regeneration patterns may be affected by the historical land use of burned areas (Baeza, Valdecantos, Alloza, \& Vallejo, 2007; Pérez, Cruz, Fernández-González, \& Moreno, 2003). Baeza et al. (2007) found that, in a region of southern Spain, previous land use (forest or cropland) determined the type of post-fire regenerating shrub. But at the same time, land owners' decisions as a response to the presence (or absence) of fire are likely to have also a determinant role in post-fire land cover dynamics (Viedma, Moreno, \& Rieiro, 2006). In fact, wildfires may offer an opportunity for land cover change, or may be a discouraging element leading land owners to stop managing their land. In summary, landscape changes in humanized fire-prone regions may result from interactions between fire regime, natural vegetation dynamics and human management decisions.

Most empirical studies about the role of fire on vegetation dynamics were carried out in burned areas, with no comparison with nearby unburned landscapes. To our knowledge, only 
two studies clearly focused on the influence of fire on landscape dynamics in the Mediterranean, by comparing burned versus unburned areas. One was carried out by Lloret et al. (2002) for a region of Catalonia (Spain). These authors compared landscape composition and dynamics during a 15-year period, and found that in burned areas shrublands were more persistent and that there was a faster transition from pine forests to shrublands. Burned areas had lower landscape diversity and larger patch sizes. The other was undertaken by Viedma et al. (2006) in central Spain. These authors monitored landscape changes during 1975-1990 in areas with different fire frequencies. They have also found a decrease in the area covered by pines and an increase in shrublands, and higher landscape homogeneity, in burned areas.

Portugal is the European country presenting the largest percentage of the territory affected by wildfires (San-Miguel \& Camia, 2009) and is also the European country presenting the largest percentage of private forests (FAO, 2005). Additionally, most of the country is characterized by very fragmented landscapes composed of very small land plots belonging to different land owners (DGRF, 2007). These aspects are likely to have strong implications on landscape dynamics and its link with wildfires. Different studies dealing with landscape dynamics in Portugal (Gaspar \& Fidalgo, 2002; Moreira, Rego, \& Ferreira, 2001; Timóteo, Bento, Rego, \& Fernandes, 2004), and elsewhere in the Iberian Peninsula (Loepfe, Martinez-Vilalta, Oliveres, Piñol, \& Lloret, 2010; Romero-Calcerrada \& Perry, 2004) have shown that land abandonment due to socio-economic changes is contributing to increase fire hazard, namely by increasing the area covered by shrublands and forests. However, the role of wildfires on subsequent land cover dynamics has not deserved a similar attention from researchers. It is important to understand which land cover transitions are associated with wildfires and which can be expected in the absence of fire, as this knowledge can help managers directing their efforts to recently burned areas in order to promote sustainable landscapes.

In the present paper we address the role of fire on the landscape dynamics of three regions in Portugal with different landscape patterns. For that purpose we characterized landscape changes during a time period of 13-15 years beginning in 1990, both overall and separately for areas that have been affected versus not affected by wildfires during that period, with the aim of answering the following research questions: (a) what is the influence of wildfire occurrence on the probability of land cover change?; (b) which land cover transitions are fire-driven? (c) what is the expected landscape composition at the end of the XXI century, based on modeled land cover transitions and according to different scenarios of fire regime?

\section{Methods}

\subsection{Study areas}

We have collected data on landscape changes and wildfire occurrence for 13- and 15-year study periods, starting in 1990, in three Portuguese fire-prone areas: Águeda (6512 ha), in the Northern Coastal region; Mação (12,177 ha), in the Central region; and Bragança (11,533 ha), in the Northeastern region of Portugal (Fig. 1). These three areas were chosen because of their distinctive proportions in land cover and high fire incidence during the study period. Águeda and Macão were selected because they include the most representative forest types in Portugal, eucalyptus and maritime pine, respectively. Bragança lacked the fast-growing eucalyptus plantations (due to the lower temperatures of this region) and had a higher proportion of native broadleaved forests.

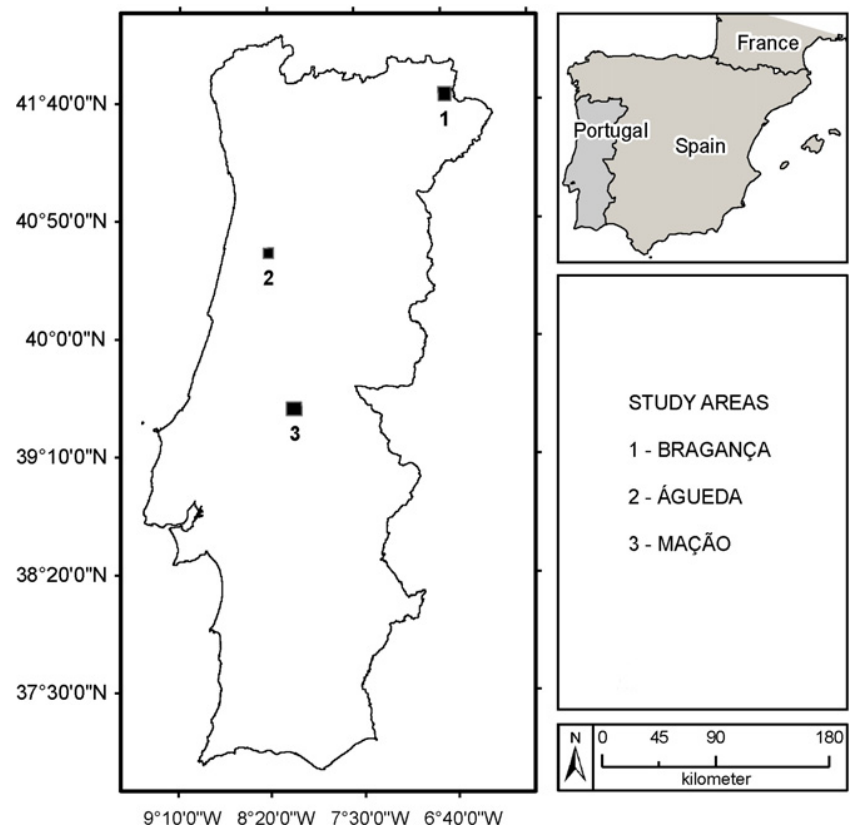

Fig. 1. Location of the three study areas.

\subsection{Characterization of land cover and wildfire patterns}

Our base map was a 1990 land-cover map for Portugal (reference scale $1: 25,000$ ) developed by the National Centre of Geographical Information. The legends of the base land-cover map were simplified to a seven-class legend considered adequate:

- Agriculture - all types of diverse agricultural mosaics and pastures, including annual crops, permanent crops (vineyards, orchards, olive groves). In Bragança, this class included recent agro-forestry plantations of chestnut (Castanea sativa Mill.).

- Shrublands - plant communities dominated by shrubs at different developmental stages.

- Conifers - artificially and naturally regenerated forests of maritime pine (Pinus pinaster Aiton). Other species of conifers are residual in our data.

- Eucalyptus - forests of blue gum (Eucalyptus globulus Labill.).

- Broadleaves - forests with different species of oaks (Quercus spp.), riparian tree species and other native broadleaves, but also including exotic Acacia spp. patches particularly in Águeda but also in Mação. In Bragança mature closed forests of chestnut (not present in the other two regions) were included in this class.

- Mixed forests of eucalyptus and conifers (mixed E-C) - mixed forests of maritime pine and blue gum in different levels of dominance, presenting in general a developed understory.

- Other mixed forests (mixed) - mainly composed of broadleaves and conifers but also broadleaves mixed with blue gum, presenting in general a developed understory.

These land cover categories occurred in all areas with the exception of eucalyptus and mixed $\mathrm{E}-\mathrm{C}$, which did not occur in Bragança.

We used 4-band digital orthophotomaps ( $0.5 \mathrm{~m}$ resolution $)$ from 2005 (Mação and Bragança) and Quickbird high resolution satellite orthorectified imagery (panchromatic band with a spatial resolution of $0.61 \mathrm{~m}$ and infrared false-color image of $2.4 \mathrm{~m}$ resolution) from 2003 (Águeda), to acquire the final maps of the study areas, 15 and 13 years after 1990 . Therefore, we have considered a 15 -year study period for Mação and Bragança and a 13-year study period for Águeda. The images were interpreted on screen (patches $\geq 0.5 \mathrm{ha}$ ) and the resulting land cover map was confirmed by field surveys. 
Photointerpretation was validated by field-checking randomly distributed sampling units of $250 \mathrm{~m}$ radius circles ( $n=15$ in Mação and Bragança, $n=12$ in Águeda). Both the 1990 and 2003/2005 land cover maps were integrated in a vector-based Geographic Information System (GIS). In both maps (initial and final), social areas and water bodies were excluded from the analysis.

Yearly maps of fire scars ( $\geq 5 \mathrm{ha}$ ) in the study areas during the period 1990-2003/2005 were assessed from cartography available in vector format from the National Forest Authority.

Maps representing the final landscape state (2003 and 2005) were intercepted with the initial maps (1990) in order to identify those areas where land cover had changed and those areas where land cover remained the same. Transition polygons smaller than 0.25 ha were not considered (each was merged with the neighboring patch with the longest shared border). Finally, this layer with transition polygons was overlaid and cross-tabulated with fire maps.

\subsection{Fire effects on the overall landscape dynamics}

To determine the relative importance of wildfires and land cover on landscape dynamics, we defined a regular grid of points which was then overlaid on each study area. The number of points was established in order to match approximately the number of polygons (homogeneous areas in terms of land cover transition and fire occurrence), considering a minimum surface of 0.25 ha. The number of sampling points was 1764 in Águeda, 2160 in Bragança and 2530 in Mação. For each point we recorded information on fire occurrence (burned - 1; unburned - 0) and on the initial and final land cover, from which we derived the change status (change -1 ; no change - 0 ) during the study period.

Logistic regression (Hosmer \& Lemeshow, 2000) was used to evaluate the influence of fire occurrence and initial land cover in 1990 (both categorical variables) on landscape changes (binary dependent variable). To assess the relative importance of these variables, we used an information-theoretical approach (ITA) (Burnham \& Anderson, 2002). The ITA looks for simplicity and parsimony of several working hypothesis and is based on finding the strength of evidence of each model, for a set of candidate predictive models. The AIC (Akaike Information Criterion) adjusted for small samples $\left(\mathrm{AIC}_{\mathrm{C}}\right.$ ) was used as a measure of information loss of each candidate model, with the best fitting model having the lowest $\mathrm{AIC}_{\mathrm{c}}$ and the highest Akaike weight $(w)$. The latter measures the probability that a given model is true, given the data and the set of competing candidate models. $\operatorname{AIC}_{\mathrm{C}}$ differences $\left(\Delta_{\mathrm{AIC}}\right)$ between each model and the model with the smaller AIC can be used to assess the relative support for the different alternative models (Burnham \& Anderson, 2002; Rushton, Ormerod, \& Kerby, 2004).

Our set of candidate models included four models: one separate model for each predictor variable (fire occurrence and land cover), one model with both variables and one last model with the two main factors and their interaction. The relative importance of each variable was also estimated by summing the Akaike weights across all models that contained that variable (Burnham \& Anderson, 2002). Model fit and predictive performance of each model were evaluated by calculating the area under the receiver operating characteristics curve (AUC) (Pearce \& Ferrier, 2000).

Since the obtained models would provide a similar change probability for all points sharing the same combination of the two categorical variables (land cover and fire occurrence) we decided to compute the average of 0 's and 1's from the original data, for each combination of the two variables in order to have a measure of dispersion (standard error) and to assess statistical significance in comparisons between burned and unburned areas. These averages represented the mean probability of change for each land cover.
Differences between burned and unburned areas were tested for statistical significance using the Mann-Whitney $U$-test.

\subsection{Fire effects on land cover transitions}

To characterize in detail the landscape changes during the study period, we computed transition matrices separately for each area using the surface (in hectares) occupied by each land cover. Each column represented the number of hectares of each land cover in 1990 converted to the different land covers in 2003/2005. Values were standardized as proportions of the total surface of each land cover in 1990, in order to obtain transition probabilities between different classes.

For each study area, matrices were built separately for the overall (matrix $O$ ), for the burned (matrix $B$ ) and the unburned (matrix $U$ ) surfaces. Therefore each matrix represented different landscape dynamics according to different fire regime scenarios. We computed a difference matrix $D=U-B$ in order to detect, for each value $d_{i j}$ the transitions with higher probability to occur in burned areas $\left(d_{i j}<0\right)$ and those transitions which were more likely to occur in the absence of fire $\left(d_{i j}>0\right)$.

\subsection{Long term landscape change scenarios}

In a further step, using the same set of transition matrices we performed a Markov analysis (Balzter, 2000) to simulate future landscape scenarios according to 15-year (13 in the case of Águeda) time-steps. This was computed by multiplying the overall vector of land cover proportions $o_{(t)}$, at year 2005 (2003 for Águeda) by the three transition matrices $(O, B$ and $U)$ in such a way that:

$o_{(t+n s)}=o_{(t)} \cdot O^{n}$

$b_{(t+n s)}=o_{(t)} \cdot B^{n}$

$u_{(t+n s)}=o_{(t)} \cdot U^{n}$

where $o_{(t+n s)}, b_{(t+n s)}$ and $u_{(t+n s)}$, represent the projected landscapes produced by the overall, the burned and the unburned transition matrices (respectively) after $n$ time-steps of $s$ years ( $s=13$ for Águeda; $s=15$ for Mação and Bragança) starting at year $t$ (2003 for Águeda; 2005 for Mação and Bragança). The final year of projections $(t+n s)$ corresponded to approximately one century after 1990 (2094 for Águeda; 2095 for Mação and Bragança). We used Euclidean distances to check that the differences of land cover proportions between consecutive time-steps at the end of this period were relatively small (less than $6 \%$, for each one of the three projections) and also to measure the differences between initial and final landscapes. These landscape projections allowed assessing the effects of wildfires on landscape dynamics and the expected landscape pattern if the modeled land cover transitions were maintained throughout time. Similarly, we assessed the trends in landscape diversity by computing the equitability index (based on the Shannon-Wiener index of diversity) for the beginning of the study period $(t)$ and for the end of the projected period $(t+n s)$, according to the three transition scenarios.

\section{Results}

\subsection{Fire occurrence and main land cover changes}

The Águeda area was mainly covered by eucalyptus (58\%) and conifers (13\%) in 1990 (Table 1 and Fig. 2). The main land cover changes during 1990-2003 were an important increase of mixed (969\%) and mixed E-C forests (352\%), and a decline of conifer $(-52 \%)$, eucalyptus $(-37 \%)$ and agricultural areas $(-23 \%)$. Overall, during the $1990-2003$ period, fire burned $33 \%$ of the area, most of which (27\%) in 1991. 
Table 1

Overall landscape dynamics for each study area and each land cover: initial, final and burned surfaces in hectares.

\begin{tabular}{|c|c|c|c|c|c|}
\hline & & Initial (1990) & Final $^{\mathrm{a}}$ & $\%$ change & Burned \\
\hline \multirow[t]{8}{*}{ Águeda } & Agriculture & 630 & 483 & -23.3 & 91 \\
\hline & Shrublands & 382 & 781 & 104.5 & 151 \\
\hline & Conifers & 857 & 414 & -51.7 & 437 \\
\hline & Eucalyptus & 3706 & 2333 & -37.0 & 1072 \\
\hline & Broadleaves & 392 & 395 & 0.8 & 124 \\
\hline & Mixed E-C & 347 & 1569 & 352.2 & 165 \\
\hline & Mixed & 35 & 374 & 968.6 & 32 \\
\hline & Total & 6349 & & & 2072 \\
\hline \multirow[t]{8}{*}{ Mação } & Agriculture & 5385 & 4778 & -11.3 & 518 \\
\hline & Shrublands & 356 & 893 & 150.8 & 133 \\
\hline & Conifers & 2066 & 1582 & -23.4 & 1416 \\
\hline & Eucalyptus & 657 & 861 & 31.1 & 133 \\
\hline & Broadleaves & 404 & 350 & -13.4 & 98 \\
\hline & Mixed E-C & 1517 & 1484 & -2.2 & 981 \\
\hline & Mixed & 574 & 1011 & 76.1 & 202 \\
\hline & Total & 10,959 & & & 3481 \\
\hline \multirow[t]{6}{*}{ Bragança } & Agriculture & 6107 & 6007 & -1.6 & 334 \\
\hline & Shrublands & 3660 & 3350 & -8.5 & 1165 \\
\hline & Conifers & 652 & 622 & -4.6 & 117 \\
\hline & Broadleaves & 712 & 1066 & 49.7 & 45 \\
\hline & Mixed & 95 & 181 & 90.5 & 18 \\
\hline & Total & 11,226 & & & 1679 \\
\hline
\end{tabular}

a 2003 for Águeda; 2005 for Mação and Bragança.
In Mação, agriculture and conifers were the main land cover classes in 1990 (49\% and 19\%, respectively). During 1990-2005 the main landscape changes were an increase of shrublands (151\%) and mixed forests (76\%) and a decline of conifers (-23\%). During the studied time period, fire burned $32 \%$ of the area, most of which (26\%) in 1991.

The Bragança area was covered mainly by agriculture (54\%) and shrublands (33\%) in 1990. The main changes during 1990-2005 were an increase of mixed forests $(91 \%)$ and broadleaved forests (50\%). Overall, during the concerned period, fire burned $15 \%$ of the study area in nine different years, particularly in 2000 (3\%) and 2004 (4\%).

\subsection{Fire effects on the overall landscape dynamics}

As a result of the logistic regression analysis, we obtained two models for Águeda with a similar fit to the data (Table 2), one including fire and land cover (Akaike weight of 0.53) and the second with these main factors and also their interaction (Akaike weight of 0.47). According to Burnham and Anderson (2002), models with $\mathrm{AIC}_{\mathrm{c}}$ differences between 0 and 2 have substantial support. Moreover, the second model presented the highest AUC (0.66). Therefore the second model $\left(\Delta_{\mathrm{AIC}}=0.3\right)$ is also considered an alternative fit to the data. In Bragança and Mação the best model for predicting land cover changes included fire, initial land cover and the interaction between these variables. Both of these models had an Akaike weight
BRAGANÇA

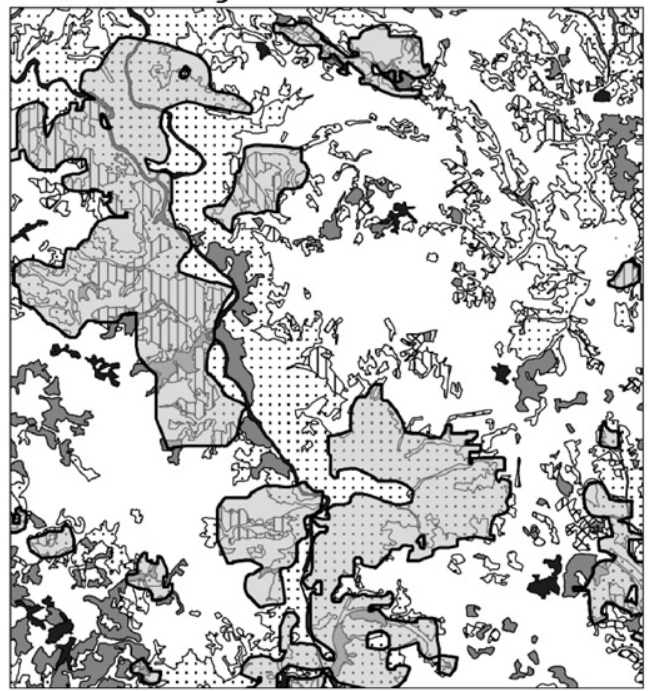

\section{MAČ̃̃O}

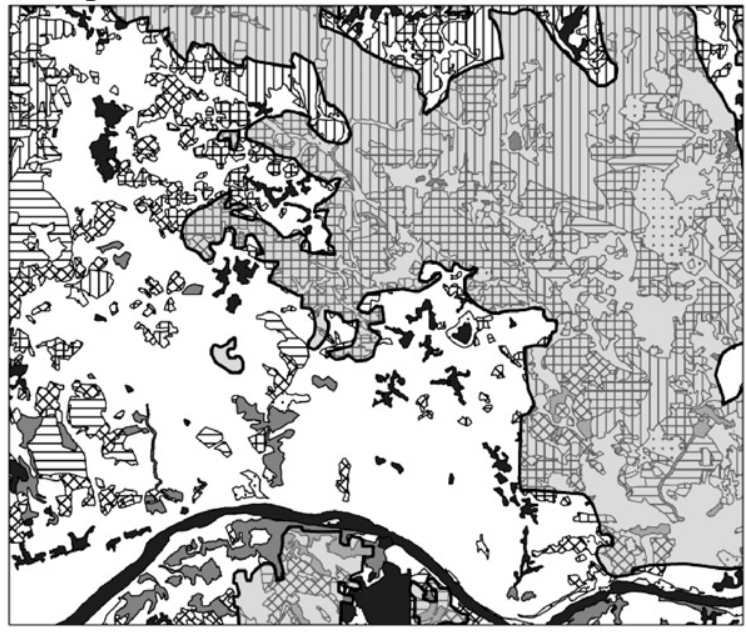

\section{ÁGUEDA}

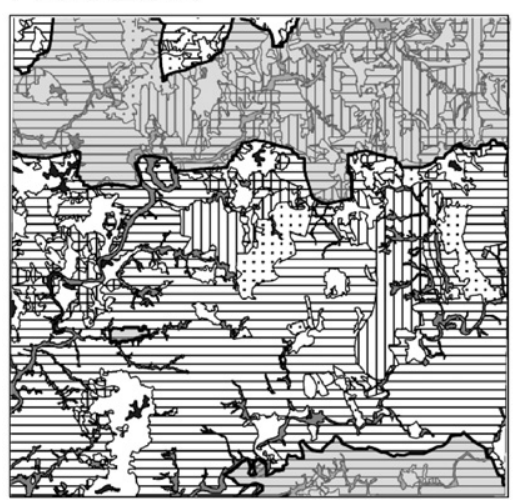

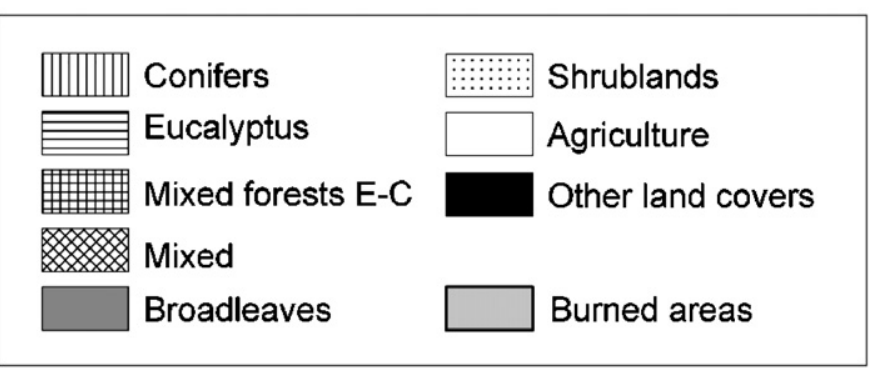
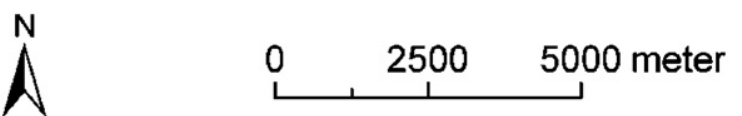

Fig. 2. Maps of the three study areas including information on land covers (in 1990) and areas burned during the study periods. 
Table 2

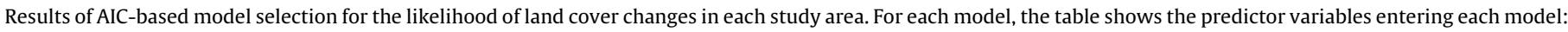

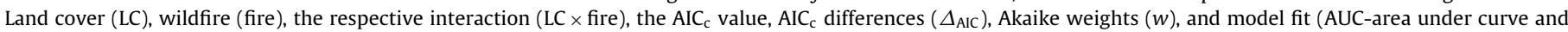
respective $p$-value). For each area, models are ordered by increasing $\Delta_{\mathrm{AIC}}$.

\begin{tabular}{|c|c|c|c|c|c|c|c|c|}
\hline & LC & Fire & $\mathrm{LC} \times$ fire & $\mathrm{AIC}_{\mathrm{c}}$ & $\Delta_{\mathrm{AIC}}$ & $w$ & AUC & $p$ \\
\hline \multirow{4}{*}{ Águeda } & $\mathrm{X}$ & $\mathrm{X}$ & & 2198.8 & 0 & 0.534 & 0.64 & $<0.001$ \\
\hline & $\mathrm{X}$ & $X$ & $\mathrm{X}$ & 2199.1 & 0.3 & 0.466 & 0.66 & $<0.001$ \\
\hline & $X$ & & & 2226.4 & 27.6 & 0.000 & 0.61 & $<0.001$ \\
\hline & & $\mathrm{X}$ & & 2307.6 & 108.8 & 0.000 & 0.56 & $<0.001$ \\
\hline \multirow[t]{4}{*}{ Mação } & $X$ & $\mathrm{X}$ & $X$ & 2349.0 & 0 & 1.000 & 0.72 & $<0.001$ \\
\hline & $\mathrm{X}$ & $\mathrm{X}$ & & 2395.2 & 46.2 & 0.000 & 0.71 & $<0.001$ \\
\hline & $\mathrm{X}$ & & & 2425.3 & 76.3 & 0.000 & 0.68 & $<0.001$ \\
\hline & & $\mathrm{X}$ & & 2495.5 & 146.4 & 0.000 & 0.63 & $<0.001$ \\
\hline \multirow[t]{4}{*}{ Bragança } & $\mathrm{X}$ & $\mathrm{X}$ & $X$ & 2081.9 & 0 & 1.000 & 0.70 & $<0.001$ \\
\hline & $X$ & & & 2158.1 & 76.2 & 0.000 & 0.66 & $<0.000$ \\
\hline & $\mathrm{X}$ & $\mathrm{X}$ & & 2159.4 & 77.4 & 0.000 & 0.66 & $<0.001$ \\
\hline & & $\mathrm{X}$ & & 2277.6 & 195.7 & 0.000 & 0.54 & 0.008 \\
\hline
\end{tabular}

of 1.00 and represented by far, the best model from the analyzed set, with a $\Delta_{\mathrm{AIC}}>45.0$ in comparison with the second best model. For all the best models, Akaike weights were similar for both fire and land cover, showing that these variables had a similar importance in explaining landscape dynamics.

According to the computation of the average change status, fire increased significantly the likelihood of change for most land covers in all three study areas (Fig. 3). Change probability
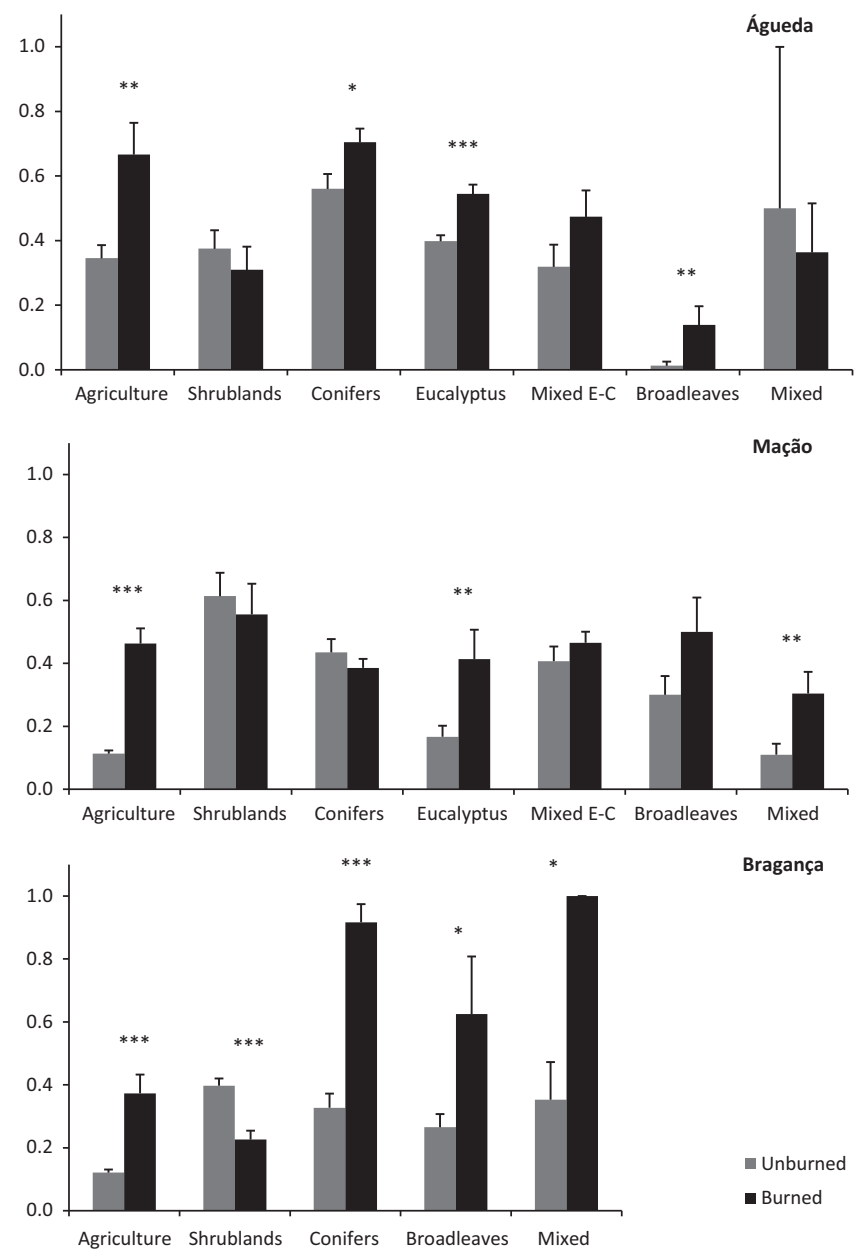

Fig. 3. Change probabilities (mean $+\mathrm{SE}$ ) for the different land cover classes and for burned and unburned areas. Asterisks indicate the significance of Mann-Whitney $U$-tests for comparisons between unburned and burned areas $\left({ }^{*} p<0.05 ;{ }^{* *} p<0.01\right.$; $\left.{ }^{* * *} p<0.001\right)$. in Águeda was significantly higher in burned areas of agriculture $(p=0.003)$, conifers $(p=0.024)$, eucalyptus $(p<0.001)$ and broadleaves $(p=0.006)$. Change probability in Mação was significantly higher in burned areas of agriculture $(p<0.001)$, eucalyptus $(p=0.004)$ and other mixed forests $(p=0.006)$. Change probability in Bragança was significantly higher in burned areas of agriculture $(p<0.001)$, conifers $(p<0.001)$, broadleaves $(p=0.031)$ and mixed forests $(p=0.043)$. Shrublands presented higher change probability in unburned areas $(p<0.001)$.

\subsection{Fire effects on land cover transitions}

The results obtained for the transition matrix in Águeda (Table 3) showed that broadleaves presented the highest persistence (96\%), whereas the lowest persistence was registered for conifer forests (35\%). The main transitions reflected a change towards mixed E-C, mainly from conifers (32\%), eucalyptus (24\%), shrublands (20\%) and agriculture (17\%). Other important transitions were towards eucalyptus forests, mainly from mixed E-C forests (13\%), shrublands (11\%) and conifers (10\%) and towards shrublands, mainly from conifers (15\%) and eucalyptus (10\%). The analysis of the effect of fire on landscape transitions (Fig. 4) showed that land cover persistence was usually higher in the absence of fire, most noticeably for agricultural areas $(d=35 \%)$ and eucalyptus forests $(d=13 \%)$. Fire favored the transitions from agriculture to shrublands $(d=-11 \%)$ and mixed E-C $(d=-13 \%)$ and from conifers to mixed E-C $(d=-15 \%)$. The absence of fire favored the conversion of conifers to eucalyptus $(d=13 \%)$ and the conversion of other mixed forests to broadleaves $(d=16 \%)$.

In Mação the land covers with higher persistence were agriculture (85\%) and mixed forests (82\%), whereas the lowest persistence was registered for shrublands (39\%). The main transitions were from shrublands to eucalyptus (23\%) and mixed E-C (17\%) and from conifers to mixed E-C (18\%). Other important transitions were the replacement of mixed E-C by shrublands (16\%), conifers (11\%), and mixed forests (11\%), the transition from broadleaved to mixed forests (11\%), and the transition of conifers to shrublands (12\%). Fire was associated with a lower persistence of the majority of land covers with the exception of shrublands $(d=-13 \%)$. Fire absence allowed the persistence of agriculture ( $d=35 \%$ ), eucalyptus, $(d=32 \%)$, broadleaves $(d=26 \%)$ and mixed forests $(d=17 \%)$. Fire favored the transitions to shrublands, mainly from broadleaves $(d=-21 \%)$, agriculture $(d=-14 \%)$, mixed $(d=-12 \%)$ and mixed E-C forests $(d=-12 \%)$. The transition from eucalyptus to mixed $\mathrm{E}-\mathrm{C}$ was also promoted by fire $(d=-28 \%)$.

In Bragança, the land covers with higher persistence were agricultural areas (86\%), whereas the lowest persistence was registered for conifer forests (55\%). The main transitions were from conifers 
Table 3

Overall transition matrices for the three study areas. Bold values indicate transitions $\geq 0.10$.

\begin{tabular}{|c|c|c|c|c|c|c|c|c|}
\hline & & \multicolumn{7}{|l|}{1990} \\
\hline & & Agriculture & Shrublands & Conifers & Eucalyptus & Broadleaves & Mixed E-C & Mixed \\
\hline \multirow{7}{*}{$\begin{array}{l}\text { Águeda } \\
\text { (2003) }\end{array}$} & Agriculture & 0.60 & 0.00 & 0.02 & 0.02 & 0.00 & 0.06 & 0.00 \\
\hline & Shrublands & 0.04 & 0.59 & 0.15 & 0.10 & 0.00 & 0.09 & 0.05 \\
\hline & Conifers & 0.01 & 0.05 & 0.35 & 0.02 & 0.00 & 0.02 & 0.05 \\
\hline & Eucalyptus & 0.09 & 0.11 & 0.10 & 0.57 & 0.01 & 0.13 & 0.09 \\
\hline & Broadleaves & 0.00 & 0.00 & 0.00 & 0.00 & 0.96 & 0.04 & 0.02 \\
\hline & Mixed E-C & 0.17 & 0.20 & 0.32 & 0.24 & 0.03 & 0.60 & 0.00 \\
\hline & Mixed & 0.09 & 0.05 & 0.06 & 0.05 & 0.00 & 0.05 & 0.79 \\
\hline \multirow{7}{*}{$\begin{array}{l}\text { Mação } \\
(2005)\end{array}$} & Agriculture & 0.85 & 0.08 & 0.02 & 0.02 & 0.06 & 0.03 & 0.06 \\
\hline & Shrublands & 0.03 & 0.39 & 0.12 & 0.03 & 0.09 & 0.16 & 0.07 \\
\hline & Conifers & 0.03 & 0.02 & 0.59 & 0.03 & 0.02 & 0.11 & 0.02 \\
\hline & Eucalyptus & 0.02 & 0.23 & 0.03 & 0.77 & 0.02 & 0.05 & 0.02 \\
\hline & Broadleaves & 0.01 & 0.04 & 0.00 & 0.00 & 0.68 & 0.00 & 0.01 \\
\hline & Mixed E-C & 0.03 & 0.17 & 0.18 & 0.10 & 0.02 & 0.54 & 0.00 \\
\hline & Mixed & 0.03 & 0.08 & 0.05 & 0.06 & 0.11 & 0.11 & 0.82 \\
\hline \multirow{5}{*}{$\begin{array}{l}\text { Bragança } \\
(2005)\end{array}$} & Agriculture & 0.86 & 0.14 & 0.08 & & 0.21 & & 0.12 \\
\hline & Shrublands & 0.09 & 0.68 & 0.31 & & 0.09 & & 0.32 \\
\hline & Conifers & 0.02 & 0.03 & 0.55 & & 0.00 & & 0.00 \\
\hline & Broadleaves & 0.02 & 0.13 & 0.00 & & 0.68 & & 0.00 \\
\hline & Mixed & 0.00 & 0.01 & 0.05 & & 0.02 & & 0.56 \\
\hline
\end{tabular}
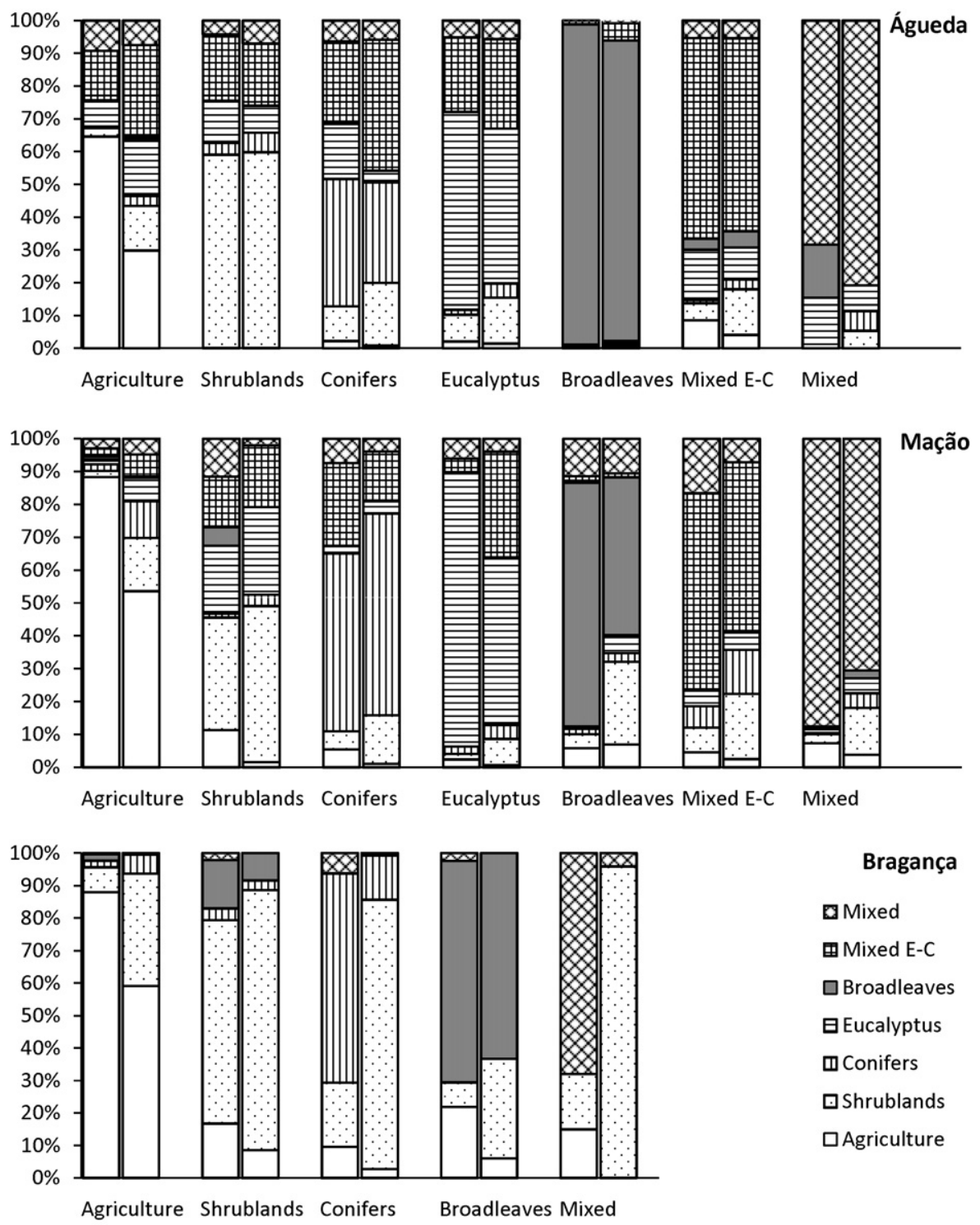

Bragança
Mixed
Mixed E-C
Broadleaves
Eucalyptus
Conifers
Shrublands
Agriculture

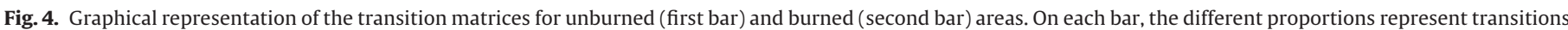
from the initial land covers in 1990 (classes on the horizontal axis) to land covers in 2003/2005 (patterns on each bar) 

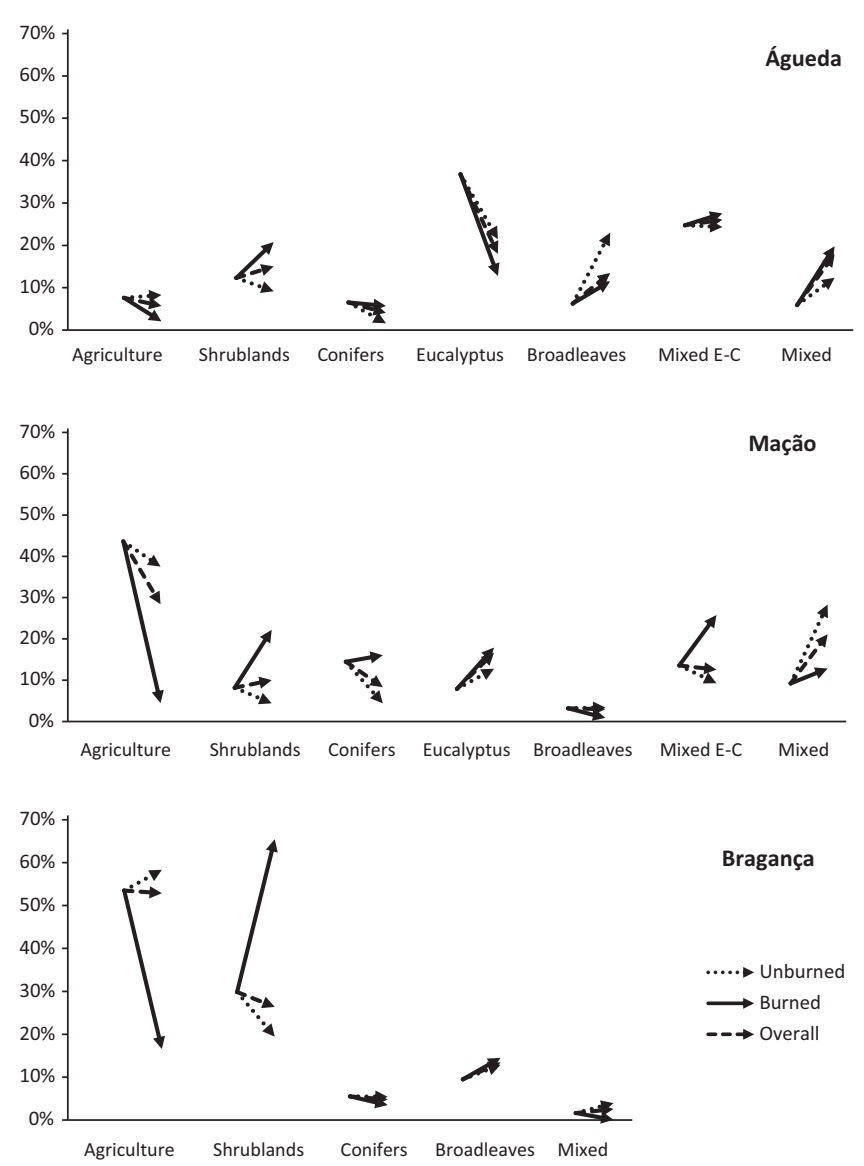

Fig. 5. Long term projected trends (2003-2094 for Águeda, 2005-2095 for Mação and Bragança) according to three different scenarios. The tip of each arrow represents the final land cover proportion, obtained by multiplying the overall landscape vector (the starting point of each arrow) by the unburned, the burned and the overall transition matrices.

to shrublands (31\%), from broadleaves (21\%) and shrublands (14\%) to agriculture, and from shrublands to broadleaves (13\%). Fire was associated with a lower persistence of the majority of land covers with the exception of shrublands $(d=-17 \%)$. Fire favored the transitions to shrublands, mainly from conifers $(d=-63 \%)$, agricultural areas $(d=-27 \%)$, broadleaves $(d=-23 \%)$ and also mixed forests ( $d=-79 \%$, but small sample size). The absence of fire favored the transition of broadleaves to agriculture $(d=0.16)$ as well as the transition of other mixed forests to agriculture $(d=0.15)$.

\subsection{Long term landscape change scenarios}

Compared to the land cover composition in 2005 (Fig. 5), and according to the overall transition matrix, the projected landscape composition in Águeda would result in a landscape dominated by mixed E-C forests (+8\%), eucalyptus ( $-50 \%)$, mixed forests $(+196 \%)$ and shrublands $(+24 \%)$. The absence of fire would result in a landscape dominated by mixed E-C forests $(+2 \%)$, eucalyptus $(-40 \%)$, broadleaves $(+228 \%)$ and mixed forests $(+112 \%)$. In contrast, a firedriven landscape dynamics would create a landscape dominated by mixed E-C forests (+13\%), shrublands ( $+71 \%)$, mixed forests ( $+227 \%$ ) and eucalyptus (-65\%). Compared to 2005, landscape diversity would be expected to increase (0.87-0.93) assuming the overall landscape dynamics. When compared with this projection, either a scenario without fire (0.87-0.91) or a complete periodic burn of the study areas (0.87-0.90), would result in lower landscape diversity. The projected landscapes differed from the initial landscape according to the following Euclidean distances: overall 23\%, burned $30 \%$ and unburned $22 \%$.
In Mação, according to the overall transition matrix the projected landscape would be dominated by agriculture $(-35 \%)$ mixed forests $(+129 \%)$, eucalyptus $(+111 \%)$ and mixed E-C forests $(-7 \%)$. The absence of fire would create a landscape dominated by agriculture $(-5 \%)$, mixed forests $(+179 \%)$, eucalyptus $(+55 \%)$ and mixed E-C forests $(-37 \%)$. Fire-driven transitions would create a landscape dominated by mixed E-C forests ( $+91 \%)$, shrublands $(+173 \%)$, eucalyptus $(+127 \%)$ and conifers $(+13 \%)$. Compared to 2005 , landscape diversity would be expected to increase $(0.85-0.92)$ assuming the overall landscape dynamics. When compared with this projection, either a scenario without fire $(0.85-0.80)$ or a complete periodic burn of the study areas (0.85-0.89), would result in lower landscape diversity. The projected landscapes differed from the initial landscape according to the following Euclidean distances: overall $22 \%$, burned $45 \%$ and unburned $21 \%$.

In Bragança, according to the overall transition matrix the projected landscape would be dominated by agriculture $(-1 \%)$, shrublands $(-12 \%)$ and broadleaves $(+41 \%)$. Compared to this current fire regime, a scenario without fire would create a landscape still dominated by agriculture $(+10 \%)$, shrublands $(-35 \%)$ and broadleaves $(+32 \%)$. In contrast, a fire-driven transition dynamics would create a landscape dominated by shrublands $(+119 \%)$, agriculture $(-70 \%)$ and broadleaves $(+57 \%)$. Compared to 2005 , landscape diversity would be expected to increase (0.71-0.74) assuming the overall landscape dynamics. When compared with this projection, either a scenario without fire $(0.71-0.73)$ or a complete periodic burn of the study areas (0.87-0.61), would result in lower landscape diversity. The projected landscapes differed from the initial landscape according to the following Euclidean distances: overall 5\%, burned $52 \%$ and unburned $12 \%$.

\section{Discussion and conclusions}

\subsection{General aspects}

The three study areas presented very different initial landscape composition, with Águeda being dominated by eucalyptus forests, Mação by agricultural areas and conifers, and Bragança by agricultural areas and shrublands. There were also differences in fire occurrence during the study period, most noticeably the fact that Águeda and Mação burned mainly at the beginning, whereas Bragança burned at the end of the study period. These differences including time-since-fire (Mouillot et al., 2005; Trabaud \& Galtiè, 1996) probably had consequences on land cover dynamics. However, some common land cover change patterns were found in all areas.

Given the characteristics of the three study areas, it is particularly relevant to separate transitions which are a consequence of management decisions from those related only with land abandonment, leading to natural vegetation succession. In this latter case we can include most transitions to shrublands, to mixed eucalyptus-conifer forests and to other mixed forests, because transitions to these land cover classes normally do not represent the result of land management decisions. On the contrary, transitions to agriculture and to eucalyptus are very likely related to an active strategy of land use change, given the artificial nature of this type of land occupation. Transitions to conifers and to broadleaves can be associated either to natural vegetation succession or to land management decisions.

\subsection{The role of wildfires}

In all three areas, both fire and initial land cover influenced the likelihood of land cover changes. Therefore, we confirmed that fire was an important driver of land cover change in all three studied areas, which is consistent with other studies (e.g. Acácio, Holmgren, 
Rego, Moreira, \& Mohren, 2009; Baeza et al., 2007). Overall, fire decreased land cover persistence, hence increased the likelihood of land cover changes. Nevertheless the interaction between land cover and fire was very important in explaining the overall landscape dynamics, as not all land cover classes presented a similar response to fire in terms of change probability.

Shrublands were an obvious exception to the general trend because, contrarily to the remaining land cover classes, fire maintained or decreased the probability of change to other land covers. There are two potential explanations for this trend: first, fire interrupts the ecological succession preventing shrublands to become forests; and second, fire acts as a discouraging factor preventing new investments in agriculture or eucalyptus plantations, for example. Previous studies from other regions (Chuvieco, 1999; Loepfe et al., 2010; Viedma et al., 2006) provided evidence that fire promotes more homogeneous landscapes as it maintains shrublands by preventing their succession to forests, and bringing forests back to a shrubland-like physiognomic stage.

As to the remaining land covers, fire consistently increased change probability i.e. decreased land cover persistence. Fire induced changes in these land covers by transforming different land cover types into shrublands or by creating an opportunity for other tree species to participate in the ecological succession, leading to mixed forests of different kinds. Similarly to burned shrubland areas, the result of active management seems to have played a less important role than nature in burned areas of the remaining land covers. In fact, although fire could create new opportunities for land cover change by land owners, this does not seem to have been the case. Burned agricultural fields and burned eucalyptus stands showed a particularly consistent higher change probability, when compared with unburned areas of these land covers. In the case of eucalyptus we could expect a higher persistence of this land cover, given the high resilience and rapid recovery of the species after fire as shown by Gouveia, Camara, and Trigo (2010) for Southern Portugal. Instead, our results suggest that fire created conditions for land abandonment, resulting in many cases in the conversion of eucalyptus into different kinds of mixed forests or shrub-dominating vegetation at the end of the study period. A similar reasoning is valid for burned agricultural areas, mainly converted into shrublands. This suggests that agricultural areas affected by wildfires were also more prone to abandonment, as previously found by Lloret et al. (2002). Although socio-economic variables are not the core issue within the present work, they are important drivers of land use conversion and should therefore be taken into account (Moreira et al., 2001; Van Doorn \& Bakker, 2007). In agricultural lands the influence of fire on land abandonment seems to be more important than for the other land uses, therefore contributing to increase the overall trend of agriculture abandonment in Portugal (Moreira et al., 2001; Nunes et al., 2005).

\subsection{The resulting landscape changes}

The major common overall changes in the three study areas were a decrease of agriculture and conifers and an increase of mixed forests of both types and shrublands. These latter land covers can be reliably associated with land abandonment. If we consider the resulting landscape changes in the three study areas concerning these land covers, there was an increment of at least 38\% of abandoned land at the end of the study period. In burned areas the increase was $42 \%$ whereas in unburned areas it was $36 \%$, which seems to confirm that fire only contributed to enhance an already existing abandonment trend.

Agricultural abandonment, widely documented for the Mediterranean region (Mouillot et al., 2005; Poyatos, Latron, \& Llorens, 2003; Pueyo \& Beguería, 2007; Romero-Calcerrada \& Perry, 2004), can explain the decline observed in farmland in all areas, and tran- sition matrices confirmed the conversion of agricultural areas into a large variety of forest types and shrublands. In Bragança the rate of loss was lower than in the other areas, but this is explained by the fact that some shrubland and broadleaved areas have been converted to agriculture (including subsidized chestnut plantations for agro-forestry). In this study area, the high transition rate of broadleaves to agriculture suggests an active land use change due to economic reasons, although this has occurred essentially in unburned areas. Similarly, in Mação there was an important transition from shrublands to agricultural areas but almost exclusively in unburned areas, confirming the role of fire in discouraging the investment in new land uses.

Consequently, the abandonment factor could explain the widespread increase of shrublands. The fact that important transition rates were observed from different forest types to shrublands, suggests that wildfires or tree harvesting followed by abandonment are the main drivers of the increase of shrubland area, by converting forests into a shrubland stage (Acácio et al., 2009; Baeza et al., 2007). In particular, the transition from conifer forests to shrublands showed high rates in all areas, which could be explained by the fact that maritime pine (basically the only conifer species) does not have resprouting capacity after fire. Persistence is dependent on the seed bank in serotinous cones, which might not exist if the stand is burned before reaching reproductive maturity (Fernandes \& Rigolot, 2007). However, some differences between areas may be attributable to time-since-fire. For example, in Bragança, the effect of fire on decreased conifer persistence was much more obvious than in the other areas, probably because fire was quite recent and the potentially regenerating conifer forests did not have time enough to grow and pass the shrubland-like stage. This area also had the highest fire-driven increases in the transition from broadleaves to shrublands, probably due to the same reason.

In the three study areas, conifers followed the general decreasing trend shown by previous national forest inventories, partly because of forest fires (DGF, 2001; DGRF, 2007). However, there were important transitions to conifers, particularly in Mação. Most transitions to conifers were fire-driven which can be related to the capacity of maritime pine to colonize burned areas. Maritime pine is known to act as a typical seeder, often presenting very high seedling densities in recently burned areas (Fernandes \& Rigolot, 2007).

The area of eucalyptus declined in Águeda (where it was more widespread) at the beginning of the study period but increased in Mação. In this latter area, most eucalyptus forests originated from former shrublands and also from agriculture. Although E. globulus regenerates in Portugal from naturally dispersed seeds (Marchante, Freitas, \& Marchante, 2008; Silva, Feith, \& Pereira, 2007), the dispersal distance should be normally limited to a few meters around the tree trunk (Potts, 1990; Virtue \& Melland, 2003). Therefore, natural seed dispersal should not be the main reason explaining the large increase observed. A more likely explanation is the result of active management due to land owner decisions to plant eucalyptus. Economic reasons may also explain the transition from conifers to eucalyptus in Águeda in the absence of fire, suggesting that this is a normal conversion process implemented by land owners, once conifer trees are harvested.

Broadleaves increased in Bragança, declined in Mação and presented a similar surface in Águeda. In Bragança they originated mainly from shrublands suggesting that secondary succession was the major driver. Transitions from agriculture in Mação could also have a similar explanation. In Águeda this forest type was mainly constituted by Acacia dealbata, an exotic invasive species, highly resilient to fire and other disturbances (Almeida \& Freitas, 2006; Marchante et al., 2008; Yongqi \& Fuwen, 2006), which may explain the high persistence of this land cover in this study area. 
In Águeda and Mação transitions from conifers and eucalyptus to mixed E-C forests were more important than transitions to shrublands. With the exception of conifers in Mação, all transitions were more important in burned areas, as revealed by the transition matrices. Given the regenerative characteristics of eucalyptus already mentioned, transitions from conifers may be partly explained by a two-stage process, where conifers were replaced by eucalyptus plantations which were then colonized by pine plants, after fire. Transitions from eucalyptus to mixed eucalyptus-conifer forests can be explained by the high spreading capacity of maritime pine (Fernandes \& Rigolot, 2007) leading to the colonization of mismanaged eucalyptus plantations, with fire playing a role in this transition (Fernandes \& Rigolot, 2007). Previous studies showed that mixed forests of conifers and eucalyptus present a high level of fire-proneness (Moreira et al., 2009; Nunes et al., 2005), suggesting that fire is creating a feedback loop, where burning changes forest composition towards higher fire hazard.

Given the small surface of mixed forests in Águeda and Bragança, results from these areas should be interpreted with caution. The observed increase in mixed forests can be interpreted as lack of management leading to vegetation succession. The original native forests in the study regions were dominated by oaks (Vasconcellos \& Franco, 1954). Oak regeneration in the understory of unmanaged conifer or eucalyptus plantations, or within shrublands and abandoned agricultural fields, is expected to result in mixed forests. This hypothesis was supported by the results of transition matrices, which showed that mixed forests originated mostly from pure conifer and pure eucalyptus forests, former agricultural land and shrublands. In Mação, broadleaves have been converted mainly to mixed forests, probably due to natural colonization by conifers given the high travelling distance of the wing-shaped maritime pine seeds

\subsection{Future landscapes}

The projection of future landscapes using the three transition scenarios revealed important differences relatively to the initial landscape. The burned transition scenario corresponded to the most different landscape in all three areas, which is relevant about the role of wildfires in shaping Mediterranean landscapes (Arianoutsou, 2001; Mouillot et al., 2005; Trabaud \& Galtiè, 1996). In terms of diversity, both burned and unburned transition scenarios would lead to more homogeneous landscapes, which is in accordance with findings from other studies (Loepfe et al., 2010; Rescia, Willaarts, Schmitz, \& Aguilera, 2010; Viedma et al., 2006).

In Águeda landscape dynamics would be mainly driven by eucalyptus since this land cover was associated with the most important changes in the landscape. The decreasing trend of eucalyptus in all scenarios has to be understood in a context where the starting landscape was strongly dominated by this land cover due to the "eucalyptus rush" in the 1980s of the previous century (Silva, Sequeira, Catry, \& Aguiar, 2007). As a result, the decrease of eucalyptus in a fire-free landscape would be compensated by the expansion of broadleaves (mainly Acacia spp.), whereas a fire-driven landscape dynamics would promote the expansion of mixed forests of both types. In Mação, landscape dynamics would be dominated mainly by the decrease of agriculture both in the overall and in the burned transition scenarios, and by the increase of mixed forests in the unburned transition scenario. In Bragança landscape dynamics would be dominated by the decrease of agriculture and the increase of shrublands in burned areas. Given the lower percentage of burned surface in Bragança, the overall and the unburned transition scenarios would result in similar landscapes (dominated by agriculture/agro-forestry).
With the exception of the two latter scenarios described for Bragança, all forecasted landscapes would present an increase of fire hazard due to the loss of agricultural areas and due to the increase of shrublands and unmanaged mixed forests of both types. Besides the reduced economic value and the higher fire hazard of these projected landscapes, those in Águeda and Mação would also have a reduced conservation value given the permanence or expansion of exotic species like Acacia spp. and E. globulus. Wildfires seem to play an important role in this trend, by enhancing land abandonment which results in less valuable and less sustainable landscapes. Due to these reasons, our findings reinforce the need of a particular attention to the management of burned areas in order to prevent landscape degradation and increasingly hazardous fire regimes.

\section{Acknowledgments}

The research work described in this paper was produced by projects: PHOENIX (contract POCI/AGR/58896/2004), funded by the Portuguese Foundation for Science and Technology (FCT); Recuperação de Áreas Ardidas funded by Fundo Florestal Permanente - IFAP (contract 200409002629 7); and FireReg (contract PTDC/AGR-CFL/099420/2008) funded by FCT. Pedro Vaz was funded by FCT (PhD grant SFRH/BD/45490/2008).

\section{References}

Acácio, V., Holmgren, M., Rego, F., Moreira, F., \& Mohren, G. (2009). Are drought and wildfires turning Mediterranean cork oak forests into persistent shrublands? Agroforestery Systems, 76, 389-400.

Almeida, J. D., \& Freitas, H. (2006). Exotic flora of Continental Portugal-A reassesment. Botanica Complutensis, 30, 117-130.

Arianoutsou, M. (2001). Landscape changes in Mediterranean ecosystems of Greece: Implications for fire and biodiversity issues. Journal of Mediterrean Ecology, 2, 165-178.

Baeza, M. J., Valdecantos, A., Alloza, J. A., \& Vallejo, V. R. (2007). Human disturbance and environmental factors as drivers of long-term post-fire regeneration patterns in Mediterranean forests. Journal of Vegetation Science, 18, 243-252.

Bajocco, S., \& Ricotta, C. (2008). Evidence of selective burning in Sardinia (Italy): Which land-cover classes do wildfires prefer? Landscape Ecology, 23, 557-567.

Balzter, H. (2000). Markov chain models for vegetation dynamics. Ecological Modelling, 126, 139-154.

Burnham, K., \& Anderson, D. (2002). Model selection and multimodel inference: A practical information-theoretic approach. New York: Springer Verlag.

Chuvieco, E. (1999). Measuring changes in landscape pattern from satellite images: Short-term effects of fire on spatial diversity. International Journal of Remote Sensing, 20, 2331-2346.

DGF, 2001. Inventário Florestal Nacional (National Forest Inventory). 3ํㅡ revisão, Direcção-Geral das Florestas, Lisbon. [in Portuguese].

DGRF. (2007). National forest strategy. Lisbon: Direcção-Geral dos Recursos Florestais.

FAO (2005). Global forest resources assessment. In FAO Forestry Paper FAO, Rome.

Fernandes, P., \& Rigolot, E. (2007). The fire ecology and management of maritime pine (Pinus pinaster Ait.). Forest Ecology and Management, 241, 1-13.

Forman, R. (1995). Land mosaics: The ecology of landscapes and regions. Cambridge: Cambridge University Press.

Gaspar, J., Fidalgo, B., 2002. Evolução do uso do solo e avaliação do valor paisagístico e de recreio na Área de Paisagem Protegida da Serra do Açor (Land use evolution and landscape and recreation value assessment of Landscape Protected Area of Serra do Açor). Silva Lusit. 10,179-194. [in Portuguese].

Gouveia, C., Camara, C., \& Trigo, R. (2010). Post-fire vegetation recovery in Portugal based on spot/vegetation data. Natural Hazards and Earth System, 10, 673-684.

Hosmer, D. W., \& Lemeshow, S. (2000). Applied logistic regression. New York: John Wiley \& Sons.

Lloret, F., Calvo, E., Pons, X., \& Díaz-Delgado, R. (2002). Wildfires and landscape patterns in the Eastern Iberian Peninsula. Landscape Ecology, 17, 745-759.

Loepfe, L., Martinez-Vilalta, J., Oliveres, J., Piñol, J., \& Lloret, F. (2010). Feedbacks between fuel reduction and landscape homogenisation determine fire regimes in three Mediterranean areas. Forest Ecology and Management, 259, 2366-2374.

Marchante, E., Freitas, H., Marchante, H., 2009. Guia prático para a identificação de plantas invasoras de Portugal Continental (Practical Guide for the identification of invasive plants of Portuguese Mainland), Imprensa da Univ. de Coimbra, Coimbra. [in Portuguese].

Mermoz, M., Kitzberger, T., \& Veblen, T. T. (2005). Landscape influences on occurrence and spread of wildfires in patagonian forests and shrublands. Ecology, 86, 2705-2715.

Mitchell, R. J., Simonson, W., Flegg, L. A., Santos, P., \& Hall, J. (2009). A comparison of the resilience of four habitats to fire, and the implications of changes in commu- 
nity composition for conservation: A case study from the Serra de Monchique, Portugal. Plant Ecology Diversity, 2, 45-56.

Moreira, F., Rego, F. C., \& Ferreira, P. G. (2001). Temporal (1958-1995) pattern of change in a cultural landscape of northwestern Portugal: Implications for fire occurrence. Landscape Ecology, 16, 557-567.

Moreira, F., Vaz, P., Catry, F., \& Silva, J. S. (2009). Regional variations in wildfire preference for land cover types in Portugal: Implications for landscape management to minimize fire hazard. International Journal of Wildland Fire, 18, 563-574.

Mouillot, F., Ratte, J.-P., Joffre, R., Mouillot, D., \& Rambal, S. (2005). Long-term forest dynamics after land abandonment in a fire prone Mediterranean landscape (central Corsica France). Landscape Ecology, 20, 101-112.

Naveh, Z. (1975). The evolutionary significance of fire in the Mediterranean region. Plant Ecology, 29, 199-208.

Nunes, M. C. S., Vasconcelos, M. J., Pereira, J. M. C., Dasgupta, N., Alldredge, R. J., \& Rego, F. C. (2005). Land cover type and fire in Portugal: Do fires burn land cover selectively? Landscape Ecology, 20, 661-673.

Pausas, J., Llovet, J., Rodrigo, A., \& Vallejo, R. (2008). Are wildfires a disaster in the Mediterranean basin? A review. International Journal of Wildland Fire, 17. 713-723.

Pearce, J., \& Ferrier, S. (2000). Evaluating the predictive performance of habitat models developed using logistic regression. Ecological Modelling, 133, 225-245.

Pérez, B., Cruz, A., Fernández-González, F., \& Moreno, J. M. (2003). Effects of the recent land-use history on the postfire vegetation of uplands in Central Spain. Forest Ecology and Management, 182, 273-283.

Potts, B. (1990). The response of eucalypt populations to a changing environment. Tasforests, 2, 179-193.

Poyatos, R., Latron, J., \& Llorens, P. (2003). Land use and land cover change after agricultural abandonment. Mountain Research and Development, 23, $362-368$.

Pueyo, Y., \& Beguería, S. (2007). Modelling the rate of secondary succession after farmland abandonment in a Mediterranean mountain area. Landscape and Urban Planning, 83, 245-254.

Rescia, A. J., Willaarts, B. A., Schmitz, M. F., \& Aguilera, P. A. (2010). Changes in land uses and management in two nature reserves in Spain: Evaluating the socialecological resilience of cultural landscapes. Landscape and Urban Planning, 96, 26-35.

Romero-Calcerrada, R., \& Perry, G. L. W. (2004). The role of land abandonment in landscape dynamics in the SPA 'Encinares del río Alberche y Cofio', Central Spain, 1984-1999. Landscape and Urban Planning, 66, 217-232.

Rundel, P. (1998). Landscape disturbance in Mediterranean-type ecosystems: An overview. In P. Rundel, G. Rizzardini, G. Montenegro, \& F. Jaksi (Eds.), Landscape disturbance and biodiversity in Mediterranean-type ecosystems (pp. 3-22). Berlin: Springer Verlag.

Rushton, S., Ormerod, S., \& Kerby, G. (2004). New paradigms for modelling species distributions? Journal of Applied Ecology, 41, 193-200.

San-Miguel, J., \& Camia, A. (2009). Forest fires at a glance: Facts, figures and trends in the EU. In Y. Birot (Ed.), Living with wildfires: What science can tell us (pp. 11-18) Joensuu: European Forest Institute.

Silva, J. N., Feith, H., Pereira, J. C., 2007a. Exploração e silvicultura pós-fogo em eucaliptais (Forest harvesting and post-fire silviculture in eucalypt stands), in: O eucaliptal em Portugal - Impactes ambientais e investigação científica (Eucalypt stands in Portugal - Environmental impacts and scientific research) (A. M. Alves, J. S. Pereira, J. N. Silva, Eds.), ISAPress, Lisbon, pp. 285-312. [in Portuguese].

Silva, J. S., Sequeira, E., Catry, F., Aguiar, C., 2007b. Os contras (The cons of eucalypts), in: Pinhais e eucaliptais (Pine and eucalypt stands). (J. S. Silva, Ed.), Público/Fundação Luso- Americana para o Desenvolvimento/Liga para a Protecção da Natureza, Lisbon, pp. 221-256. [in Portuguese].

Timóteo, I., Bento, J., Rego, F. C., \& Fernandes, A. (2004). Changes in landscape structure of the natural park of Alvão (Portugal). In S. Mazzoleni, G. di Pasquale, M Mulligan, P. di Martino, \& F. Rego (Eds.), Recent dynamics of the Mediterranean vegetation and landscape (pp. 211-216). New York: John Wiley \& Sons, Ltd.

Trabaud, L., \& Galtiè, J.-F. (1996). Effects of fire frequency on plant communities and landscape pattern in the Massif des Aspres (southern France). Landscape Ecology, $11,215-224$.

Van Doorn, A. M., \& Bakker, M. M. (2007). The destination of arable land in a marginal agricultural landscape in South Portugal: An exploration of land use change determinants. Landscape Ecology, 22, 1073-1087.

Vasconcellos, J., Franco, J., 1954. Carvalhos de Portugal (Oaks of Portugal), in: Anais do Instituto Superior de Agronomia, Instituto Superior de Agronomia, Lisbon. [in Portuguese].

Viedma, O. (2008). The influence of topography and fire in controlling landscape composition and structure in Sierra de Gredos (Central Spain). Landscape Ecology, 23, 657-672.

Viedma, O., Moreno, J., \& Rieiro, I. (2006). Interactions between land use/land cover change, forest fires and landscape structure in Sierra de Gredos (Central Spain). Environmental Conservation, 33, 212-222.

Virtue, J. G., \& Melland, R. L. (2003). The environmental weed risk of revegetation and forestry plants. Adelaide: Department of Water Land and Biodiversity Conservation.

Yongqi, F., \& Fuwen, W. (2006). Invasive potential of two introduced tree species: Acacia mearnsii and Acacia dealbata. Scientia Silvae Sinica, 10, 48-53. 